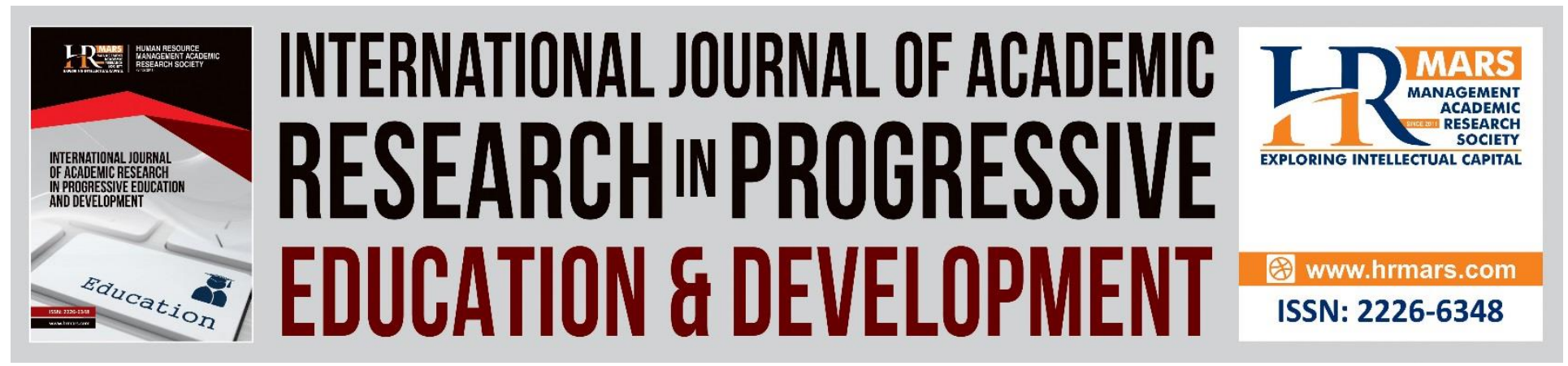

\title{
Enhancing Higher Order Thinking Skills (Hots) Through Literature Components in ESL Classrooms
}

\section{Yoges Gopalan, Harwati Hashim}

To Link this Article: http://dx.doi.org/10.6007/IJARPED/v10-i2/9673

DOI:10.6007/IJARPED/v10-i2/9673

Received: 11 February 2021, Revised: 13 March 2021, Accepted: 31 March 2021

Published Online: 19 April 2021

In-Text Citation: (Gopalan \& Hashim, 2021)

To Cite this Article: Gopalan, Y., \& Hashim, H. (2021). Enhancing Higher Order Thinking Skills (Hots) Through Literature Components in ESL Classrooms. International Journal of Academic Research in Progressive

Education and Development, 10(2), 317-329.

Copyright: (C) 2021 The Author(s)

Published by Human Resource Management Academic Research Society (www.hrmars.com)

This article is published under the Creative Commons Attribution (CC BY 4.0) license. Anyone may reproduce, distribute, translate and create derivative works of this article (for both commercial and non-commercial purposes), subject to full attribution to the original publication and authors. The full terms of this license may be seen at: http://creativecommons.org/licences/by/4.0/legalcode

Vol. 10(2) 2021, Pg. 317 - 329

http://hrmars.com/index.php/pages/detail/IJARPED

JOURNAL HOMEPAGE

Full Terms \& Conditions of access and use can be found at http://hrmars.com/index.php/pages/detail/publication-ethics 


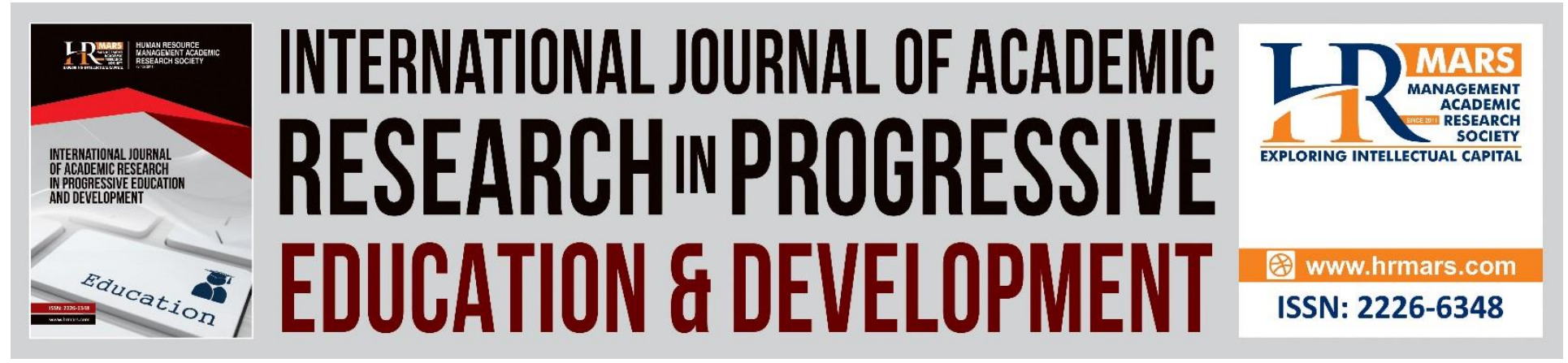

\title{
Enhancing Higher Order Thinking Skills (Hots) Through Literature Components in ESL Classrooms
}

\author{
Yoges Gopalan \\ SMK Raja Mahadi, Malaysia \\ Harwati Hashim \\ Faculty of Education, Universiti Kebangsaan Malaysia
}

\begin{abstract}
In preparing students for $21^{\text {st }}$ century, the importance of teaching higher order thinking skills is questionable. Yet, many educators and employers express their concern that young Malaysians especially fresh graduates are unable to think critically and creatively. Therefore, this paper presents a review of extant literature on studies related to HOTS through literature in ESL Classrooms. Many tools have been used for language teaching to teach the language more efficiently over the course of time. Nevertheless, it is widely accepted that literature has proven to be one of the best and most beneficial teaching resources. Literature is currently being taught by adhering to the syllabus merely for examination purposes, instead of teaching to cultivate understanding and appreciation. Change needs to be taken place thereby immediately. The instillation of HOTS through literature is seen as a great benefit. English Literature is now collocated in the preliminary National Education Blueprint (2013-2015) as a method to help improve English proficiency of students. In accordance with the transformation of education in Malaysia, this paper explains the various types of literature that exist in the current curriculum and how it can be integrated in English lessons to instil Higher Order Thinking Skills. This paper suggests that English literature should be reconceptualised given its ability to help educate and train young Malaysians to think critically based on the Taxonomy Bloom (Revised Anderson) as it caters for both advanced and beginner level learners. Literature should therefore be used as a bridge for educating young Malaysians to be innovative and to think critically.
\end{abstract}

Keywords: Higher Order Thinking Skills (HOTS), ESL, Literature

\section{Introduction}

The provisional National Education Blueprint (2013-2025) was launched on 11 September 2012 by the then Prime Minister. One of the key goals of the Blueprint is to reshape and improve the education system to ensure Malaysia's competitiveness at the international level. In the Blueprint, English literature has a significant role to play in fostering English proficiency. English 
literature is seen to play two roles in our Malaysian primary and secondary curriculum, which are literature as a study (referred as the big "L") for upper secondary students, and literature as resource (referred as the small "I") for primary and lower secondary students.

In addition to encouraging English literacy, it is also generally recognized that the literature aspect has proven to be the strongest and most valuable tool for instilling HOTS. Before the introduction of the blueprint, teachers were often used to repeat learning, which emphasizes the memorization of facts. Learning activities too were more focused on the instructor or educator, making students passive recipients of information. Nonetheless, the latest MEB curriculum (2015-2025) has changed the approach to emphasize on meaningful learning through engaging, constructive and long-lasting learning experience as stated by DeWaelsche (2015). Teachers are also expected to promote the development of higher order thinking skills (HOTS) among students.

One of the core elements of the advancement of $21^{\text {st }}$ century education is the implementation of HOTS, which incorporates logical, critical, reflective, metacognitive, and creative thinking. Literature integrated lessons are notified as a chance to advance HOTS in English. This paper discusses many aspects of the content of a literary work based on its genres, which may help readers to think critically. Literacy tasks normally provide rooms for interpretation that further help in the development of HOTS. Even so, many teachers are reluctant to focus on the implementation of the HOTS through literary elements. This may be largely attributed due to the new CEFR-aligned KSSM syllabus which does not require any testing of the literature questions at the UPSR or PT3 examinations. This paper discuses about the implementation of HOTS through literature.

The idea of reinforcing the teaching of HOTS in Malaysia's Education System started in the year 2009 when students aged 14 and 15 years began to sit for the PISA and TIMMS examinations. The Malaysia Education Board decided to reform teaching and learning methodologies as these students performed quite badly in both the examinations. Looking at the perspective of language, Malaysia ranked 55 with cumulative points of 414 in the year of 2009 and placed at $59^{\text {th }}$ in the year 2012 for the reading literacy tested in PISA examination (OECD, 2018). At the recent released PISA 2018 results Malaysia collected a cumulative point of 415 for its reading literacy (OECD, 2018). Even though, the recently released PISA results by OECD was a big relieve for all including the Ministry of Education as it has showed a slight improvement; but we are still lagging behind the neighbouring country, Singapore in PISA and TIMMS examinations.

Malaysia as a developing nation with multiple races and cultures is at a crossroad between national standards and international education standards. It is an eye opener for the entire nation when the results of PISA and TIMMS clearly reflects that the students still lack understanding in tackling the questions related to Higher Order Thinking (HOT) because most of the PISA and TIMMS questions are based on analysis, synthesis and evaluation concepts. Even though the HOTS questions have found their way into the national level examination since 1993, our students are still struggling to be on par with international students due to many reasons. The most commonly discussed or frequently debated reason is the credibility of the teachers in teaching HOTS. Many researchers such as Seman, Yusoff, \& Embong (2017) and Nagappan (2001) have debated about this and they merely revert to the teachers by stating that one of the main reasons students cannot perform well in the international exams are due to teachers failure in 
Vol. 10, No. 2, 2021, E-ISSN: 2226-6348 @ 2021 HRMARS

teaching HOTS in classroom. The former director of the Examination Syndicate Datin Nawal Salleh also once commented in a newspaper interview that teachers are not prepared to develop HOTS (The Star, 2018).

Therefore, this paper presents a review of extant literature on studies related to HOTS through literature in ESL Classroom. It is a writing on HOTS and how it is important and more importantly why teachers must focus on it. The paper presents an understanding of opportunities within the ESL lesson and how HOTS is applied in it as well as how HOTS can be easily practised using literature components such as short story, drama, novel and poetry. All these will be analysed with a core aim of enhancing HOTS through literature components in ESL classrooms.

\section{Higher Order Thinking Skills (HOTS)}

Singh et al (2018) pointed out that HOTS reflect students thinking ability. Singh and friends added that if it is present and incorporated in pedagogical components then there is an expected success in the worlds' education system. The critics always aver that students be made to transit to a deep conceptuality of ideas from the portrayal of rote memories of ideas. Higher order thinking according to Brookhart (2010) can be placed in three groups; the ones that relate it to transfer, those who relate it to critical thinking and lastly those who associate its manifestation in ability of learners to solve problems. In transferring, Brookhart (2010) argued that students get the concept they utilize in the solving of problems, and this is where higher order thinking is portrayed most. Mostly higher order thinking opens the chances for students to apply class concepts to outside life (Brookhart, 2010). In this case learners transfer learned concepts to real life rather than remembering what was done in class without having to apply it. Brookhart (2010) pointed out that critical thinking involves being reasonable and reflective at the same time and this gives an opportunity for learners to decide on what to do and believe as well. Adding to that, Singh et al (2018) stated that learners can reason, question, investigate, observe, describe, compare, connect check how complex and explore all available viewpoints by practicing HOTS. He further argued that these concepts enable a learner to become critical and analytical at the same time. Through the support of arguments from Yee et al. (2013) research, it is noted that all learners who can use higher order thinking skills can always find new ways of solving daily challenges as well as making acceptable decisions.

According to Arbain \& Nur (2017), speeches from students, while in class should not be neglected as they help students develop easiness with expressing themselves, thinking and ability to solve problems as they speak out. English speaking abilities thus should not be underestimated, and learners should have a chance to practice grammar, fluency, and comprehension skills as this gives them power to understand oneself (Leong \& Ahmadi, 2017). The ability to have students have better skills in English has led to reinforcing of HOTS which is being attested for the input it has brought in education (Purnama, \& Nurdianingsih, 2019). This inclusivity has changed the education sector as Purnama and Nurianingsih argued. The critics further aver that all students who have HOTS are likely to be more successful than those with Lower Order Thinking Skills (LOTS). Similarly, Tanujaya, Mumu, \& Margono (2017) pointed out that the intellectual portray eminent from these students will be witnessed in next levels of study. In addition, Hasan and Pardjono (2019) argued that HOTS have a relation with how ready students are to work and this is attributed to the fact that its teaching methodology is always 
learner centred. Thus, Chun and Yen (2019) stated that problem-based learning, brainstorming, constructivist learning, thinking map and inquiry learning are practices often applied in HOTS teaching. According Tikhonova and Kudinova, (2015) when a teacher teaches HOTS it is majorly based on the revised bloom's taxonomy which focuses analysation, evaluation, and creating. These sentiments that are stated by Julianingsih et al (2017); Fanani (2018). They also added that HOTS is a representative of a complex and context thinking process that is rich and centred on reflection, metacognitive, logic and critical analysis of phenomena.

Nourdad et al (2018) argued that Teaching of HOTS to students influence positively on how they read their comprehensions and so the HOTS syllabus should be emphasized. Its major noticeable impact is the improvement of reading abilities of learners. Thus, just like Brookhart (2010) argued, teachers should always avoid any short comings and give learners new assessments often as they help to boost their higher order thinking skills. Brookhart (2010) pointed out even when learners complain, giving new skills and testing is the way to go as it opens and exposes the students to critical thinking. Teachers who want their learners grow intellectually should thus focus on HOTS. Brookhart (2010) stated that teachers should expose the students to HOTS through their lessons. For instance, every time students read a novel, they should not feel like it is a new experience, their knowledge on HOTS should guide them through dealing with ideas in the novels, solve problems and critically think through.

\section{HOTS in ESL}

Marianne \& Marguerite (2014) pointed out that teaching of English as a second language involves those whose English is not their first language; and often is referred to as ESL. In this case a teacher meets learners of various mixed abilities, which could mean a teacher adopts different language level in teaching or even a different style of teaching the learners of missed ability. Thus, learners are likely to have varied abilities that will see them grasp the English being taught differently. Besides that, teachers should be aware of these mixed abilities and find better means of capturing the varied strengths and weaknesses of learners. This paper recommends HOTS as it is possible to help learners to develop problem solving and critical thinking abilities even to phenomena of outside the classroom.

McNeil (2011) recommended a move from lower level thinking to higher level thinking which is referred to as scaffolding, in the teaching of English literature and other concepts. This is attributed to Bloom's Taxonomy as well as Webb's knowledge depth. This is a concept that is highly recommended for ESL teaching as students end up progressing from lower level of thinking to higher one. This taxonomy originated with Benjamin Bloom, back in 1956 due to his experience in educational matters. The taxonomy of Bloom consists of six stages that are commonly known as hierarchical. This implies that the higher-level skills are more cognitively challenging, first of all. Secondly, they also suggest that the ability to master a higher skill in the taxonomy means the ability to master all other levels below that level or that the abilities have already been mastered at the lower level. In the revised taxonomy, the levels of information, comprehension, implementation (remembering, understanding and applying) are also referred to as the lower order skills with the lowest knowledge. The higher order skills are known to be analysis, synthesis and evaluation with evaluation holding the highest position in the taxonomy. Each taxonomy 
INTERNATIONAL JOURNAL OF ACADEMIC RESEARCH IN PROGRESSIVE EDUCATION AND DEVELOPMENT

Vol. 10, No. 2, 2021, E-ISSN: 2226-6348 @ 2021 HRMARS

level is followed by a corresponding query in Table 1.1, which represents the cognitive demands it places on the students.

Table 1: Bloom's and Anderson's taxonomies and representative literature questions.

\begin{tabular}{|l|l|l|}
\hline Bloom (1956) & Anderson et al. (2001) & $\begin{array}{l}\text { Example Questions related } \\
\text { to Literature. }\end{array}$ \\
\hline Knowledge & Remembering & $\begin{array}{l}\text { Who are the main characters } \\
\text { of the story? }\end{array}$ \\
\hline Application & Understanding & $\begin{array}{l}\text { What was the problem the } \\
\text { main character had to solve? }\end{array}$ \\
\hline Analysis & $\begin{array}{l}\text { How are the personal } \\
\text { problems of the characters in } \\
\text { the story similar to the ones } \\
\text { that real people face? }\end{array}$ \\
\hline Synthesis & Analysing & $\begin{array}{l}\text { What literary devices are } \\
\text { being used to convey to the } \\
\text { reader the character's } \\
\text { feelings? }\end{array}$ \\
\hline Evaluation & Evaluating & $\begin{array}{l}\text { Based on the story you have } \\
\text { read, how effective were the } \\
\text { strategies the characters took } \\
\text { to overcome the problems } \\
\text { that they faced? }\end{array}$ \\
\hline
\end{tabular}

Sources from Samad, A.A. (2004). Essentials of language testing for Malaysian teachers.

The two apparent differences between the taxonomy of Bloom and the revised taxonomy proposed by Andersen et al. are that, first, the revised taxonomy uses verbs for each level instead of nouns, and secondly, the highest level is now create and no longer assess in the revised taxonomy. The use of verbs tends to stress learning as a tool rather than a commodity. Therefore, teachers and learners should concentrate on the required behaviour rather than abstract notions or principles. In the updated taxonomy, the current highest level stresses the value of the ability to construct (or suggest something new) as an aim in education that is in line with students' contemporary educational objectives of significance and creativity. Compared to evaluating, which focuses only on an entity or piece of information that already exists, the greater emphasis on developing often seems more desirable. The model of HOTS emphasises on cognitive, psychomotor, and affective domains of teaching and learning. In the HOTS method a teacher lets learners understand how to acquire knowledge, comprehend it, apply, analyse, synthesise, and evaluate (Nourdad, 2015). These are the concepts that Nourdad (2015) believed can be very valuable in the teaching of English as a second language. A teacher should focus first on educating 
learners on these concepts bearing in mind that the concept or the language being taught is wholly new to learners. However, when these concepts are grasped and applied, then the entry behaviour of learners in the classes becomes of less importance as learners learn how to analyse and conceptualise ideas on their own.

In ESL, all the aforementioned stages, guide learners into making critical decisions as well as been able to judge how invaluable information given to them is. In a review of existing practices on HOTS, Chinedu et al (2015) was able to note how impactful HOT was in general learning, with is this paper coming in to point out that it could be the only thing needed in perfecting teaching of ESL. Researchers thus have come out to pint a lot of cognitivism in students who were taught using HOT strategy. A research by Ahiri et al (2013) discussed that depending on different learners' abilities, different concepts of HOTS should be employed in order to create students who have ability to think critically and solve problem independently. A study by Jones (2015) reported an excessively large difference in teachers who used lower order methods to those who used higher order methods in instruction. According to Lateef et al (2016) in a study conducted on university learners, it was evident that learners could as well improve their HOT skills, and this was manifested in high academic performances.

This paper pints out that in the teaching of HOTS to ESL speakers opens room for the internalization of competencies through which learners are able to learn positive traits, boost critical thinking, and be disciplined in monitoring oneself and one's thoughts. Findings by Masoudi (2018) thus compliment this study. He argued that HOTS is a concept that should be included in the teaching of EFL. However, this paper adds to knowledge since it centres on ESL. HOTS In Relation to Literature Components

The reader response theory of Rosenblatt (1982) affirms that a literary text is merely a text with words before the readers carry into learning their prior and present knowledge, behaviours, beliefs and cultural roles that the text shows meaning to them. This promotes the personal and sincere engagement of the text that helps to build the HOTs of the students as a text can be interpreted in various ways as it communicates with different people or even the same people who under different circumstances and occasions of reading the text.

Mustakim et al (2014) argued that Literature subject is one of the subjects that aim at creating students who are potentially holistic, and balanced. This is due to the ability that literature mirror a society (Marianne \& Marguerite, 2014). HOTS help the ESL learners use knowledge developed in this way to grow harmoniously and good mannered. The literature components as argued by Mustakim et al (2014) as well enhances students' proficiency in language. HOTS give these learners an opportunity to be themselves, generate the aesthetic nature of literature alongside giving it some meaning. This comes from the ability of learners to learn on themselves, think, solve problems, and attach meaning to give work. It becomes a form of appreciation of the creativity that authors and poets incorporate in the creation of literary texts. According to Marianne and Marguerite (2014), English teaching is not aimed at addressing learning only but also developing good interpersonal relationships and aesthetics that is informational. Thus, HOTS become a very good strategy that learners of literature can apply to derive meaning from literary texts and link the same meaning to their own lives. Laskar (2007) mentioned that, "In proper environment of tolerance and freedom of expression; literature exposes people to ambiguity and new situations that encourages judgement and discovery - 
essentially aiding in the creation of a self apart from the group. Individuality is fostered and freedom of expression is encouraged, all furthering the development of critical thinking".

Brookhart (2010) pointed out that HOTS is an improvement of the Blooms taxonomy and focuses on transfer above everything else. In this transfer learners gain knowledge and can transfer it to other aspects of life. Through adoption of critical thinking, they are able to read literature which could be short stories, drama, novels or poems and transfer them in the analysation of their daily live happenings. Bearing in mind that literature is a manifestation of happenings in a society it is likely that an autobiography, a novel, drama, or poetry piece can reflect and happening in life or one about to happen. If leaners of English as second language conceptualise this, they will be able to infer and solve problems that they face in daily lives. Being a second language, literature is introduced to their learning process so that it can motivate them due to the different stylistic devices that can be found in it as well as humour. Thus, teachers will understand that the incorporation of HOTS as a pedagogical method will be a means to help students in improving their proficiency level. This is because literature involves a lot of reading, response to novels, poems, or drama texts, gaining insights from poets or authors slices of life being able to comprehend and appreciate each piece (Radzuwan Abdul Rashid \& Vethamani, 2010). This helps learners of second language to understand that learning English is not a punishment but been provided with a mirror through literature to which they can relate and review their lives. 
Vol. 10, No. 2, 2021, E-ISSN: 2226-6348 @ 2021 HRMARS

Table 2. Some of the reasons why literature is such a valuable resource in enhancing students HOTS:

\begin{tabular}{|c|c|}
\hline Universality & $\begin{array}{l}\text { Literature is universal in the sense that it } \\
\text { examines the human being in detail. As a } \\
\text { result, it will never be outdated. }\end{array}$ \\
\hline Non-triviality & $\begin{array}{l}\text { In a literary text, even minor information may } \\
\text { have a significant impact and even serve as } \\
\text { symbols. }\end{array}$ \\
\hline Personal relevance & $\begin{array}{l}\text { In literature, anyone will find something that } \\
\text { is relevant to her own life. A king and a } \\
\text { janitorial workers can both identify with } \\
\text { Raskolnikov in Crime and Punishment, so it's } \\
\text { easy to conclude that literature unites all } \\
\text { people. }\end{array}$ \\
\hline Variety & $\begin{array}{l}\text { Literature has a lot of variety in terms of } \\
\text { vocabulary, imagination, and the objects used } \\
\text { in the text, among other things. }\end{array}$ \\
\hline Interest & $\begin{array}{l}\text { Since the main emphasis is on the human } \\
\text { being, both readers would find it fascinating. }\end{array}$ \\
\hline Economy and suggestive power & $\begin{array}{l}\text { Literature says more than it reads in terms of } \\
\text { economy and suggestive strength. The ideas } \\
\text { and philosophies established over the course } \\
\text { of King Lear's masterpiece have been in } \\
\text { volumes. As a result, literature is both succinct } \\
\text { and suggestive in nature. }\end{array}$ \\
\hline Ambiguity & $\begin{array}{l}\text { Ambiguity is one of the qualities that } \\
\text { literature loves bearing. The attraction and } \\
\text { interest in the work is sparked by the curiosity } \\
\text { sparked by uncertainty. }\end{array}$ \\
\hline
\end{tabular}

Sources from Bağatur (2015)

Through the ability to transfer and think critically as provided in HOTS, learners of English as a second language are able to appreciate the culture of writes or from whose perspective the story is told as well as relate with the characters and their own life. Similarly, literature encompasses writings by very many authors and thus, learners are able to analyse all these writings critically and appreciate the good writers and comment on the bad and why they get these views about these writes (Radzuwan Abdul Rashid \& Vethamani, 2010).

\section{Pedagogical Implication of Application of Hots}

According to Marianne, and Marguerite (2014) a language teacher and especially those who teach it as a second language should be well aware of the best strategies that can be used in the teaching of English language to students. Mustakim et al (2014) recounts that teachers have a mission to ensure learners grasp what is taught, and this is only possible through adoption 
of the right methodologies in learning. Mustakim and friends thus reaffirm that HOT skills are one of the fruitful methods in delivering education to learners and thus it is recommended in the teaching to none-native speakers of English. According to Vijayaratnam (2012) the country requires "thinking" students who can respond to real-world demands on a continual basis. Especially in the teaching of literature components such as short stories, novels, poems and drama this concept is said to be very invaluable in the opening of learners minds and improves the reading especially of drama books, poems and novels which is the beginning of learning. The implication of adoption of HOTS through literature is that it brings the learners closer to the subject they are learning, they are able to walk the lives of characters found in the books and solve problems at hand (Bağatur, 2015).

Higher order thinking (HOT) concept is pivotal in teaching (Mustakim et al., 2014). This is because it stresses on thinking and this promotes the metacognitive abilities of learners. Through this way learners are not only able to understand literature concepts but also link them to other subjects they learn in class. According to Bağatur (2015), this is an important method in the teaching and learning process. On the teaching process it makes the work of the teacher easy and this time they are not just the source of knowledge. It offers a chance to the learners also to contribute to the learning process through solving of problems as they interact with characters. HOT skills as pedagogical methods boost the thinking ability of the learner and the learner becomes fast in conceptualization of concepts and this fastens the learning process Vijayaratnam (2012). It makes it easy for learners to get done and create room for other learners as they use the gained language in their daily chores (Mustakim et al., 2014). Marianne \& Marguerite (2014) argued that HOT is amongst the highest level of cognateness and is helpful to students in dominating learning process and grasping a lot within a short time. This makes it easy even to teach short stories, poems, novels, and drama all at once since the mind of the learner is programmed through skills adopted through HOT. HOTS is a very essential pedagogical method due to its ability to boost creativity and critical thinking process. It is a methodology that provides room for ESL to become critical, develop pedagogy of creative thinking, idealise perspectives and develop insights that are deeply thought.

Findings by Mustakim et al (2014) proved that HOT skills are some of the best pedagogical approaches that an English teacher can adopt in the execution of their duties. This is because they present a study where a teacher employs a variety of methods for learners to understand literary texts; in this study it will employ two strategies which are the Question Answer Relationship and De Bono's six thinking caps. Even with various methods adopted HOTS received a lot of acclaim from learners as it provided them with an opportunity to solve problems by themselves and think critically. HOTS is even seen to promote the literacy levels of learners who had limited proficiency in their language, and which hindered how they conceptualized literature concepts. This method offered learners a chance to express thinking powers in creative and critical manner. According to Salina Mustakim \& Lebar (2012), aver that many are the times when thinking is ignored in teaching process and this limits the chances of learners to grow. In the teaching of literature, it is very paramount, and the only way learners can understand alongside liking the subject. Teachings of HOTS is thus one of the best methodologies that teachers can adopt as a pedagogical skill. Its significance over other pedagogical methods cannot be overlooked. 


\section{Conclusion}

This paper has reviewed literature on HOTS and ESL with a view to establishing the past papers arguments on how to enhance Higher Order Thinking Skills (HOTS) through Literature Components in ESL Classroom. This research claimed emphatically that literature is a source of inspiration and literary imagination for students in which literature broadens the learners' perspectives and minds in order to attempt Higher Order Thinking Skills. Furthermore, literature enables students to acquaint themselves with the worlds of others and to gain a new perspective on the universe. At the same time the selection of the literature texts too play a great role in this research. Literary texts beyond the syllabus could be used in further studies to be more specific of students' preference of the literary texts and look into how it helps students to think critically in a more effective way. This study also stressed the use of HOTS because it is able to increase students' imagination and inspire them to share constructive thoughts and ideas. ESL learners basically have the potential to think critically and creatively in accordance with best practices. Similarly, it is found that there is a connection between language development and thinking, implying that HOTS being included in the curriculum. As a result of this study, HOT skills have been found to be successful in the teaching of literature components such as short stories, novels, poetry, and drama, as this principle can help students develop their reading and learning abilities. Teachers may use this opportunity to improve students' analytical thinking by teaching them how to analyse and evaluate literary texts, which involves them in seeing relationships between events, drawing inferences, analysing events, synthesising facts, and evaluating the text, as literature is integrated into the English Language syllabus in Malaysia. It has been established through this review that HOTS based on the different concepts through which it is implemented, it is viewed as the best method that can be taught to learners of English as a second language and specifically concepts of literature. This is due to the diversity through which literature is portrayed. Making learners delve in a world of creativity and ability to solve problems by themselves. Understanding that literature is a way of living then expand it to learners' abilities to solving or understanding even literature concepts that are numerously available outside the classrooms. Researchers have pointed out that the teaching of HOTS is very instrumental and the fact that this study focuses on ESL a topic not tackled by many, then proves that this paper is a contribution to knowledge.

\section{References}

Abd. Samad, A. (2010) Essentials of language testing for Malaysian teachers. Universiti Putra Malaysia Press, Serdang, Selangor. ISBN 9789673441693

Ahiri, J., Dunifa, L., Tanduklangi, A., \& Ghani, A. (2013). The effect of learning strategies on HigherOrder Thinking skills students with different learning styles. International Journal of Science and Research, 4(9), 1204- 1211.

Arbain, A., \& Nur, D. R. (2017). Techniques for teaching speaking skill in Widya Gama Mahakam University. Script Journal: Journal of Linguistic and English Teaching, 2(1), 13-25. Https://doi.org/10.24903/sj.v2i1.80.

Bağatur, S. (2015). Teaching language through the use of literature in ESL classes with the implementation of CEFR. International Journal of Social Sciences and Education Research, 3(2), 531-539. 
Brookhart, S. (2010). How to Assess Higher Order Thinking Skills in Your Classroom, ASCD. Retrieved from http://www.ascd.org/Publications/Books/Overview/How-to-AssessHigher-Order-Thinking-Skills-in-yourclassroom.aspx

Chinedu, C., Olabiyi, O., \& Kamin, Y. (2015). Strategies for improving higher order thinking skills in teaching and learning of design and technology education. Journal of technical education and training, 7(2), 35-43

Chun, T. C., \& Yen, M. (2019). The teaching of Higher Order Thinking Skills (HOTS) in Malaysian schools: Policy and practices. Malaysian Online Journal of Educational Management (MOJEM), 7(3), 1-18.

DeWaelsche, S. A. (2015). Critical thinking, questioning and student engagement in Korean university English courses. Linguistics and Education, 32, 131-147.

Fanani, M. Z. (2018). Strategi pengembangan soal HOTS pada kurikulum 2013. Edudeena: Journal of Islamic Religious Education, 2(1), 57-76. Https://doi.org/10.30762/ed.v2i1.582.

Hasan, A., \& Pardjono. (2019). The correlation of higher order thinking skills and work readiness of vocational high school students. Jurnal Pendidikan Teknologi dan Kejuruan, 25(1), 5261. Doi: https://doi.org/10.21831/jptk.v25i1.19118.

Jones, Z. M. D. (2015). The Effects of Higher Order Thinking Skills and Lower Order Thinking Skills on Academic Achievement of Students in World History Class (Doctoral dissertation).

Julianingsih, S., Rosidin, U., \& Wahyudi, I. (2017). Pengembangan instrumen asesmen HOTS untuk mengukur dimensi pengetahuan IPA siswa di SMP. Jurnal Pembelajaran Fisika, 5(1), 5968.

Laskar, B. (2007). Critical thought and literature in the Japanese university EFL classroom. The Journal of Kanda University of International Studies, 19, 159-169.

Lateef, A., Dahar, M.A., \& Latif, Kh. (2016). Impact of higher order thinking skills of university students on their academic performance. Pakistan Association of Anthropology, 28(2), 2031-2035.

Leong, L. M., \& Ahmadi, S. M. (2017). An analysis of factors influencing learners' English speaking skill. International Journal of Research in English Education, 2(1), 34-41. Https://doi.org/10.18869/acadpub.ijree.2.1.34.

Marianne Celce-Murcia; Marguerite Ann Snow (2014). Teaching English as a Second Or Foreign Language. Cengage Heinle. ISBN 978-1-111-35169-4.

Masoudi, S. (2018). A content-based analysis of the activities in Iranian senior high school textbook. Unpublished M.A. thesis. University of Tabriz. Tabriz: Iran

Mcneil, R. C. (2011). A program evaluation model: using Bloom's taxonomy to identify outcome indicators in outcomes- based program evaluations. Journal of adult education, 40(2), 2429.

Nourdad, N. (2015). Responses to mediation for six levels of reading comprehension questions based on bloom's taxonomy. The Iranian EFL journal, 11(3), 94-111.

Nourdad, N., Masoudi, S., \& Rahimali, P. (2018). The effect of Higher Order Thinking Skill instruction on EFL reading ability. International Journal of Applied Linguistics and English Literature, 7(3), 231-237. Https://doi.org/10.7575/aiac.ijalel.v.7n.3p.231.

OECD (2018) https://www.oecd.org/pisa/publications/PISA2018_CN_MYS.pdf 
Purnama, Y. I., \& Nurdianingsih, F. (2019). The impact of Higher Order Thinking Skills (HOTS) instructions in teaching EFL speaking skill from the perspective of students' motivation. Lingua Cultura, 13(4), 313-319. Https://doi.org/10.21512/lc.v13i4.6105

Abdul Rashid, R., \& Vethamani, M. E. (2010). Approaches Employed by Teachers in Teaching Literature to Less Proficient Students in Form 1 and Form 2, 3(4), 87-99.

Rosenblatt, L. M. "The literary transaction: Evocation and response." Theory into practice 21.4 (1982): 268-277.

Salina Mustakim \& Othman Lebar. (2012). Contemporary Children's Literature to Enhance Thinking Skills: Issues and Challenges. International Conference on Multidisciplinary Research. Pulau Pinang: Universiti Sains Malaysia.

Samad, A. A. (2004). Essentials of language testing for Malaysian teachers.

Singh, R. K. A., Charanjit K. S. S., Tunku, M. T. M., Nor, A., Mostafa \& Tarsem, S. M. S. (2018). A Review of Research on the Use of Higher Order Thinking Skills to Teach Writing. International Journal of English Linguistics; Vol. 8, No. 1; ISSN 1923-869X E-ISSN 19238703.

Tanujaya, B., Mumu, J., \& Margono, G. (2017). The relationship between higher order thinking skills and academic performance of student in Mathematics instruction. International Education Studies, 10(11), 78-85. Https://doi.org/10.5539/ies.v10n11p78.

Tikhonova, E., \& Kudinova, N. (2015). Sophisticated thinking: Higher order thinking skills. Journal of Language \& Education, 1(3), 12-23.

Vijayaratnam, P. (2012). Developing higher order thinking skills and team commitment via group problem solving: A bridge to the real world. Procedia-Social and Behavioral Sciences, 66, 53-63.

Yee, M. H., Widad, B. O., Jailani, B. Md Y., Tee, T. K., Razali, B. H., \& Mohamad, M. M. B. (2013). The Level of Marzano Higher Order Thinking Skills among Technical Education Students. International Journal of Social Science and Humanity, 1(1), 121-125. 